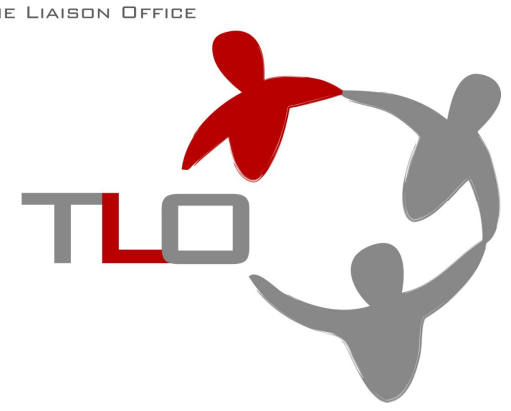

\title{
Khost's Tribes: Between a Rock and a Hard Place
}

\section{Summary}

- Tribal unity in Khost has slowly eroded over the past 30 years, due to internal leadership divisions exacerbated by pressure from foreign, Afghan and Pakistani Islamist insurgents, as well as the international military.

- The Afghan government has contributed to the weakening of tribal leaders by failing to develop a tribal engagement strategy that could have prevented a power vacuum subsequently exploited by militants.

- The current insurgency and counterinsurgency dynamics is eroding tribal leadership, which is under pressure from both sides.

- Nonetheless, tribal elders wish to be included in important decisionmaking processes, as well as in a reconciliation process. They see themselves as the main viable interlocutors with 'their' Taliban.

- The government must formulate a coherent tribal engagement strategy to help the Southeast region out of its present quagmire.

HE INR I CH BÖLL STIFTUNG
The Liaison Office is grateful for funding provided by the Heinrich Böll Stiftung to its programmes in Paktia and Nangarhar.

\section{I ntroduction}

Khost is one of Afghanistan's Southeastern provinces on the country's border with Pakistan. Since 2005, the region has been increasingly destabilised by the Haqqani-led insurgency, which over the years has weaved a tight web over the local population and which transits across the province's porous border with Pakistan with relative ease.

Current military operations in the region led by international and Afghan forces, as well as diplomatic pressure on neighbouring countries, are part of counterinsurgency efforts to stabilise Khost province. However, the conflict between international military forces, the Afghan government and the Haqqani-led insurgency in Khost is putting considerable pressure on local tribal leaders who are often forced to deal with a number of very different stakeholders in order to survive. Tribal leadership is crucial to contributing to stability by bridging the gap between communities 
and the government, yet these leaders are increasingly caught between the international military, the Afghan government and the insurgency.

Shedding light on the relationship between the state and tribal leaders is crucial to understanding the current situation, not only in Khost, but in Loya Paktia in general. ${ }^{1}$ Since 2001, the new Afghan government has failed to formulate a coherent tribal engagement strategy to bring tribes on board. As a consequence, tribal leaders in Khost have felt, and still feel, sidelined, which has had the adverse effect of rendering Khost a haven and transit route for insurgents as well as bolstering cross-border religious networks, some of which are putting enormous pressure on the local population (mullahs included) to support an increasingly robust insurgent network.

The failure to develop a tribal engagement strategy is concerning, given that state policy towards tribes in Loya Paktia has been a central concern of all Afghan rulers since the establishment of the modern Afghan state, an issue which has at times been partly placated through the implementation of a tribal policy by the state designed to co-opt tribes. ${ }^{2}$

Circumstances today certainly cannot be compared to what they were during the times of King Nader Shah or Zahir Shah, when the tribes of Loya Paktia were held in high esteem by the central administration and accorded a number of privileges, including partial autonomy from the state.

As a result of 30 years of war, migration, and changing economic conditions and lifestyle, tribal structures in Khost have partly eroded. Since the coup d'état of the People's Democratic Party of Afghanistan (PDPA) in April 1978 and the ensuing jihad, factional commanders and mullahs emerged as community leaders, providing communities with protection and guidance in times of great instability and challenging tribal leaders' traditional authority. This has fostered a number of social divisions within tribes themselves, which are still very much felt to this day.

Furthermore, while resource-based and family disputes have always existed in tribal communities, the erosion of tribal leadership has weakened their ability to resolve them and implement decisions or resolutions, which has led to a reemergence of protracted inter- and intratribal conflicts. These are having a devastating effect on people's livelihoods and general security in the province, compounded by the manipulation of outside actors, such as insurgents or strongmen. 
While the war-induced processes of social change and resource conflicts cannot be reversed, the current Afghan administration has exacerbated them by its failure to formulate a clear tribal engagement strategy. Acknowledging the importance of tribal leadership, this brief argues that defining a tribal engagement strategy (taking into account religious leadership and networks as well) may well be the government's last chance to ensuring the type of stability that could help the Southeast region out of its present quagmire, provided the right focus and approaches are taken and supported by both the Afghan Government and International Community.

\section{Khost at a Glance}

Khost province has two distinct characteristics. It remains a volatile part of the country but also has the vibrant atmosphere of a relatively prosperous economic hub, which sets it apart from the rest of the region. Given Khost's strategic location and cultural and economic wealth, the province's importance in the region cannot be overstated.

With direct transit links to Pakistan (North Waziristan and the Kurram Agency) and significant local investment, Khost has developed into a vibrant regional market, especially given the strengthening of cross-border trade relations since the war, facilitated by refugee movements between camps and vibrant Pakistani market towns such as Parachinar (Kurram Agency), Miram Shah (North Waziristan) and Peshawar (Khyber Pakhtunkhwa). ${ }^{3}$ Remittances from migrant workers, particularly from the Middle East, Gulf Arab States, China and Pakistan also contribute significantly to the economy.

Agriculture is the main source of income for a large number of people, and the province enjoys an extremely favourable climate compared to neighbouring Paktia and Paktika provinces; however an underdeveloped and ill-maintained system of irrigation and ineffective traditional methods of farming limit production.

The adverse security situation, enabled largely by the province's porous and troubled border with Pakistan and an increased influx of insurgents that have weaved a tight web over the local population over the years, has severely hindered socio-economic development and the government and international community's ability to have a positive impact on people's lives. There remains a great need for development and the general provision of basic services. 


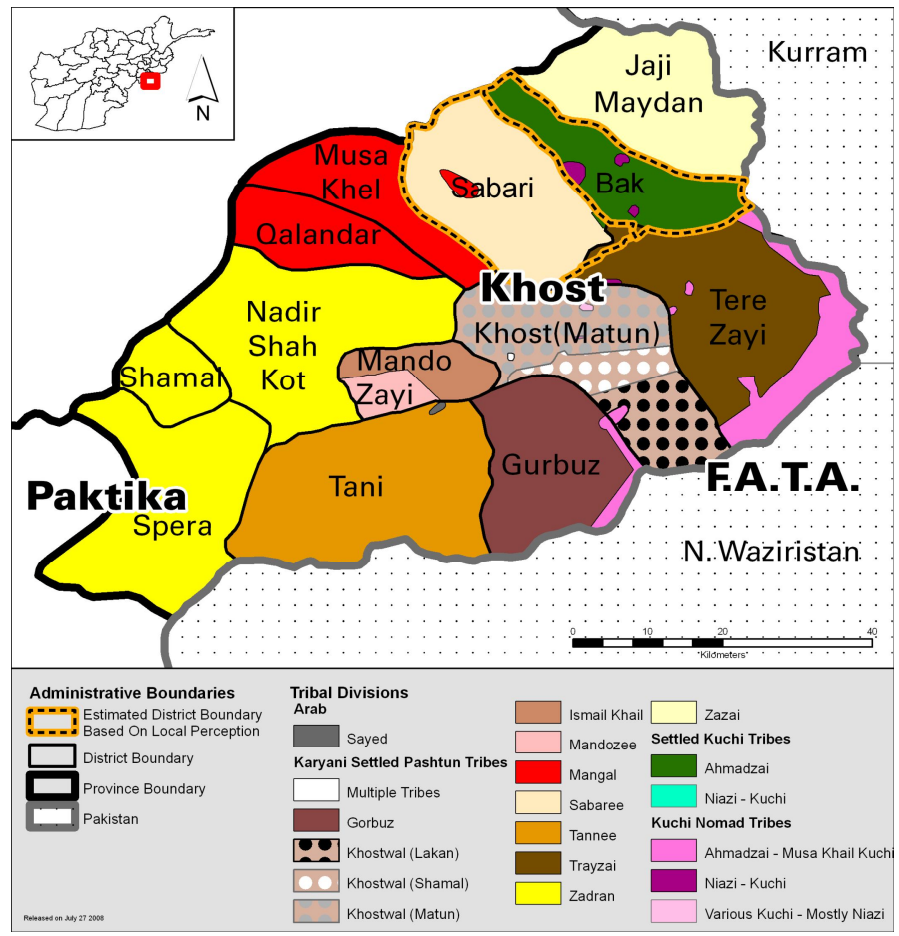

Figure 1. Khost

Khost hosts a significant educated, middle-class population and also has a (relatively) new university, built with $U A E$ funding, which opened in March 2008. The overall literacy rate is higher than in other provinces in the Southeast (25$30 \%)$. Most schools are concentrated in Khost centre and the surrounding urban areas, while districts and rural areas rely mostly on unofficial madrassas funded and maintained by the local community. There is a vibrant and active student life. Khost University currently has over 3,400 students between the ages of 19 and 34 . The province's large student population is a fertile recruiting ground for political networks and activity. Unfortunately, there is significant pressure on students to belong to particular factions or political parties, the main ones being Hizb-e Islami (both Gulbuddin and Khalis -though the latter to a lesser extent) and Leftist groups on the other. ${ }^{4}$ Many social, political and religious movements grew out of the opposition between former Leftists and their Islamist rivals in the province. $^{5}$ Indeed, Khost has a high degree of political diversity with many political parties ${ }^{6}$ and numerous supporters, as well as a number of local shuras (tribal councils) with social and political motives (e.g. the Jihadi Shura, Anjuman-i- Samoon, certain religious shuras such as the Etihad-ul Madares and former Leftist groups). ${ }^{7}$

Ongoing land-related conflicts amongst many of the tribes in Khost, most notably between the settled population and the Kuchis, further complicate provincial relations. Traditional methods for solving disputes remain of great importance to local communities, particularly given the significant number of unresolved land or resource disputes (the discovery of chromite in districts such as Tani and Dwa Manda has created a number of tensions, as well as ongoing cross-border timber smuggling). Indeed, formal state conflict-resolution methods are often avoided due to the exaction of bribes in order to solve cases and the time it takes to settle disputes. 


\section{Khost's Tribes}

CSO statistics in 2004 put the population at 939,334 , though this is a gross estimation; by and large Khost's population are Pashtun Sunni Muslims. Approximately $98 \%$ of the population live in rural areas. The main tribes are:

- Zadran: in Nader Shah Kot, Dwa Manda and Spera districts.

- Mangal: in Musa Khel and Qalandar districts.

- Tani: in Tani district

- Sabari: in Sabari district (also called Yaqubi)

- Zazi: in Zaji Maidan district

- Gurbuz: in Gurbuz district

- Ismail Khel and Mandozai: in Mandozai district

- Babakar Khel: in Bak district

- Matoonwal: in Matun Khost centre

- Lakan: in Lakan, Khost centre

- Shamalwal: in Shamal, Khost centre

- Terezai (also known as Alisher), Qadam, Landar, Sadaq, Kotkai: in Terezai district

- Kharseen: Shamal, Khost Centre

- Muqbil: in Nader Shah Kot district

Khost province also has a population of $\mathrm{Kuchi}^{8}$ nomads whose numbers vary with their seasonal migration. Among the estimated 104,965 Kuchis living in Khost, $75 \%$ are long-range migratory and $25 \%$ are settled. Amongst the long-range migratory Kuchis, generally over $50 \%$ of the community migrates seasonally to different areas. The most important areas for the long range migratory Kuchi during the summer are Paktia, Wardak, Paktika, Ghazni and Zabul. An estimated 74,179 individuals migrate across the border in winter, which would raise Khost's Kuchi population to 179,144 , making it the province with the second highest Kuchi population in the country, after Nangarhar. ${ }^{9}$ Indeed, the Kuchis became an important military/political /economic force during the jihad and played a crucial role in overrunning the provincial capital from the PDPA. The tensions between Kuchis and settled Khosti tribes began to increase over time as large numbers of refugees began to return to the province.

\section{Tribal Contracts of the Past}

Until the negative effects of war and the lack of a government tribal engagement policy were felt, two principle factors favoured the degree of integrity within Pashtun tribal structures in Loya Paktia: the administrative status of the province under the regime of Zahir Shah, and the nature of the terrain. ${ }^{10}$

Many of the tribes in Loya Paktia have always considered themselves as having been instrumental in safeguarding Afghanistan's traditional ruling elite and the border with Pakistan. For example, they helped re-establish the leadership of the Mohammadzai dynasty in 1929, helping to topple Habibullah Kalakani (aka Bacha e Saqao). King Amanullah Khan $^{11}$ who by this time was in Italy, had also been opposed by Loya Paktia's tribes for his reformist policies. The tribes of the Southeast thus helped to maintain important ties to the ruling family, thereby ensuring solid relations between the Southeast region and the centre. ${ }^{12}$

Because of the military power and autonomy of its tribes and services rendered to the King, Loya Paktia benefited from a special tribal administrative status until the 1978 coup d'état (Ghazni did not, as only a part of 
this province was included in Loya Paktia). State penetration and encapsulation of the local Pashtun tribes proved more difficult and local tribal leadership was less co-opted as the state was less successful in drawing tribal leaders to the administrative centre in the city, thereby removing them from their tribal base, as in other places, such as Kandahar or Jalalabad.

Where it was in force, this special administrative status helped preserve the integrity of Pashtun tribal structures to an extent unseen in other parts of the country, giving these areas unique features such as the resilience of a functioning system of informal justice based primarily on Pashtunwali; the resilience of the arbakai system (tribal policing mechanism), as well as the preservation of signs of tribal identity. ${ }^{13}$

\section{Effects of War, Politics, and Migration on Tribes}

Since the 1970s, tribal leadership has slowly eroded, exacerbated throughout the 1980s, when the fighting which followed the Soviet invasion prompted large swathes of the population to relocate to camps along the Pakistani border. Many tribes were divided at this point, with tribal leadership severely affected by this dislocation, engendering at times physical separation from tribal communities, but more so due to the factional allegiances and increasing importance of commanders and mullahs as social leaders.

During the jihadi era, factional commanders would scout the camps for recruits to fight the Russians; they arrived with money, vehicles and weapons and were easily able to pick out young recruits for the US-backed war effort.

“They picked strong young men who would obey orders, but they paid no attention to the tribal leaders. This had a deeply divisive and undermining effect on the authority of tribal leaders in the camps".

Many of the refugees from Khost moved to the Aigharo camp in Pakistan and joined either Hizb-e Islami (Gulbuddin or Khales) or Jamiat factions. During the war, mullahs rose in importance and status through their role as chief propagandists of the factions and by providing guidance to the people. .Jihadi commanders began to challenge the authority of tribal leaders within communities, as the latter saw commanders and mullahs as fighting a just and noble cause in the name of Islam. These processes had a lasting impact, and continue to this day as 
members of the insurgency and religious leaders do not look to traditional tribal authority.

During the jihad, many mullahs and school-age children from Khost, and indeed throughout the region, received education and attended courses in madrassas and seminars in the FATA agencies of the Pakistani border region. These madrassas did propagate a more radical doctrine of Sunni Islam and called for a political Islam. Its continuing influence in the border areas is significant and is an important ideological component of the current situation. Not only did it reduce the influence of tribal elders, but also the standing of mullahs adhering to the traditional Deobandi madrassas, which traditionally had a more individual approach to religion and were most often apolitical. It is from these madrassas that the Taliban later emerged. A number of people believe that part of the current local religious leadership is leading the insurgency in Khost. Indeed it appears that today the main powerbrokers are found among the religious networks in Khost, who are working against tribal leaders, particularly in trying to mute the leadership of those tribes that are considered relatively strong, such as the Zazi, the Mangals, the Zadrans, Tani and the Gurbuz.
At times this is done through force. There have been a number of apparently targeted killings of tribal elders in the province. One Mangal elder from Musa Khel stated that in the past two to four years, a number of elders from Bak, Sabari, Tani, Dwa Manda and Musa Khel had been killed. In Dwa Manda, seven elders from the same tribe from Said Khel village had been killed in the past four months, though apparently no one knew who had killed them.

Among those community leaders that remained in Khost during the jihad, many formed alliances with the Soviet-backed PDPA government, for ideological or practical reasons. The Zazi tribe in northern Khost, for example, tended to join the government's security organs as they were generally well educated, and subsequently given positions within the government. Religious leaders did not have as much of a hold among the Zazi tribe as they do in other areas, mainly because the Zazi were not as prominent mujaheddin fighters as others.

The consequence of the political choices made by tribal leaders in the past, to support the PDPA or go into exile, are still very much relevant today. Yet in a somewhat ironic twist of history, it seems as though those tribes that sided with the PDPA government in the past are now 
less affected by insurgency infiltrations. Areas where tribes were stronger among the mujahideen factions, and in particular where factions struggled for power in the past, are some of the most insecure areas today.

When General Khailbaz (himself a former Khalqi from Zazi Maidan, currently serving as Chief of Police in Ghazni), formed the Khost Provincial Forces (KPF) following the fall of the Taliban in 2001. His men, many of them former Khalqis, were subsequently integrated into the formal ANSF structures of the interim and then elected government. They were also hired to protect and escort Coalition Forces in the province. To this day, many of the young men working for the US military are former Khalqi-turned-KPF guards, and have maintained relatively close relations with the provincial authorities and security organs.

This has been criticized by other tribes, and as a consequence, strong divisions between tribes began to emerge based partly on political affiliations since 2004. Khost has begun to divide along different fault lines, with Haqqani and Mansurbacked communities on one side, Hizb-e Islami backed communities on another ${ }^{14}$ and government supporters on yet another.
In certain districts, such as Sabari and Bak, the conflict lines between Hizb-e Islami and Haqqani supporters are the greatest cause of insecurity. With the Haqqani network having been weakened in recent months due to drone attacks across the border close to neighbouring Miram Shah, and Hizb-e Islami gaining strength, particularly in its traditional strongholds of Bak, Sabari, Khost centre and now Terezai districts in Khost, it is likely that security will worsen in these areas, as the Haqqani group attempts to maintain its influence in the province.

The current escalation of violence further weakens tribal leaders who are simply incapable of putting up any effective resistance to the different conflicting insurgent networks. Sabari district is described as completely lawless and one of the most insecure districts in the province, which can arguably be attributed to a breakdown in tribal unity. Indeed when asked which tribe in Khost faced the most difficulties and was the most fragmented, local respondents unanimously answered: the Sabari tribe, highlighting their opinion with statements such as '50\% of the tribe' have links to al Qaeda and 'other insurgents', or "They have been crushed as a tribe". Khost's former Deputy Governor Tahir Khan Sabari, who is from the district, has been 
unable to make any trips to the district as not even his own tribe can guarantee his security. There is no government presence beyond the district centre (which is in fact the case for a number of districts in the province).

\section{A lack of tribal engagement policy as a factor of tribal erosion}

The erosion of tribal structures is also the result of government actions and inaction. The PDPA government had two strongly differing tribal engagement strategies. They initially attempted to weaken the tribal system in an effort to "modernise" the country, but later used tribal policing mechanisms to support the state. In contrast to the PDPA, the current government lacks a tribal engagement strategy and as a consequence, the tribal leadership feels sidelined by the Afghan government, which, they feel, does not consult with them on important matters, such as the hiring of government officials, questions of reconciliation or the coordination of international military operations and raids.

Until recently, the Mangal tribe in Khost was relatively strong and able to prevent insurgents from transiting through their areas. In 2003, a broad tribal agreement among the Mangal sub-tribes of Musa
Khel and Qalandar, as well as the Mangal tribe in neighbouring Paktia province, to sign a 21-article tribal agreement (or taroon) to support the government and punish those found providing shelter to insurgents, and refusing any insurgent presence in their districts.

However over the past eighteen months, this agreement has broken down and these two Mangal districts have been infiltrated and are being used as transit routes or staging grounds for attacks on the government or ANSF, with no resistance from the Mangal tribe.

In addition to an almost complete lack of Afghan security forces in certain areas, members from the Mangal tribe pointed to the fact that a poorly chosen district governor could have a serious effect on security in an area. In Musa Khel district, a Mangal stronghold, a former district governor exacerbated existing tensions among some of the Mangal sub-tribes, thereby prompting a spate of intra-tribal disputes.

In the case of the Zadran tribe, this increased withdrawal of support for the government is also getting stronger. A Zadran tribal elder stated angrily that neither the government nor the Taliban provided security, but that the tribe itself did: 
"We have received no support from the government. Over time, the government has ignored us, and they fear strong tribal leadership. This is why we are weaker now. This is why the distance between the government and tribes has become wider. There has been no reconstruction in our areas. Spera is the worst place, tribal unity here has been weakened a lot, and tribes now support the insurgents, though some work with the government."

This is a jarring reminder to tribal elders today of the low regard in which they feel they are held by the current government, contrasting starkly with their privileged status some decades ago.

\section{Sabari elder:}

"Past governments used to take into account advice from tribal elders. When someone was arrested, tribal elders were always easily able to negotiate their release. But now elders aren't important. There are threats from all sides. When I was living in the district, I was constantly investigated."

"Tribes aren't as strong as they used to be, they were ignored by various governments. Those who were patriotic to the country were killed or threatened or exiled by different sources. Today, the government should strongly support the tribes. For example, the government should consult with tribal elders when hiring people to work with the ANSF. But they just pick up drug addicts from the streets. This really has an effect on tribes, because they don't feel important".

According to a member from the Tani tribe, elders could play an instrumental role in defusing tensions within the provincial government, as they have in the past, particularly between former Provincial Governor Jamal and Chief of Police Commander Aryub. ${ }^{15}$

Another elder stated that only through tribal elders would any legitimate process of reconciliation take place ${ }^{16}$, but that tribes would need to be provided the financial support necessary in order to reach out to the 'Taliban in their tribes', in order to invite them to talk, and find out what their grievances and conditions are.

The government's inability or unwillingness to help solve local disputes exacerbates feelings of marginalization and helplessness. Indeed when tribes themselves can find no lasting solution to a land issue (such as the Balkhel-Sabari land dispute in Sabari along Paktia's Jani Khel border), and government efforts have either failed or been non-existent, tribes have voiced their support and admiration for alternative power-brokers:

“The government does nothing to help us resolve our disputes, which is why we are now referring them to the Taliban to solve. For example, there was a conflict over a mountain in Dwa Manda three months ago; the Taliban came in a group and sat with both conflict parties and asked 
questions, then they made a decision according to Sharia Law. If there is a big conflict, they go back to Miram Shah and discuss it there. Most of the people like them and want them back. The only people who want the Government here are the ones who have some economic benefit they can get from them. The Taliban defend the poor people".

Neither the district nor provincial governments have been able to address such problems, or rather they are not seen as legitimate or effective negotiators, as officials themselves are sometimes complicit in such conflicts (generally favouring one group over another for the right price, or based on political / factional allegiances).

Not all tribes face this problem, however, and it seems as though the tribes that had less involvement in the mujahideen structures, thus the war, are better off today. The Mandozai and Ismail Khel tribes, for example, regard themselves as strong tribes in the province (as do the Zazi, Mangal and Tani tribes) and support their claim by explaining that in case of any internal disputes, the heads of each sub-tribe come together to resolve the issue. The Ismail Khel, for example, comprise around 30,000 members, according to one of the tribe's leaders, who in turn are divided into six subtribes. Each sub-tribe has five to six tribal leaders, who convene when there is a problem.

Traditional tribal policing mechanisms (arbakai) are not used as much today as in the past, however some tribes still very much rely on their own tribal resources to maintain security in their areas. In Tani district, where security is comparatively good, the Tanis still employ their own tribal members to act as watchdogs and whistle-blowers.

"If something happens in Tani, generally the tribe gets together to identify what has happened and to launch an investigation. Before there were no means of communication, such as phones. We used to use the system of 'dol', where we would beat drums to inform people in other areas that something had happened."

\section{Tribes: caught between a rock and a hard place}

The security situation throughout Khost remains tense and in certain areas, volatile. Khost is consistently one of the provinces with the most kinetic activities in the country, with security forces and government officials being the main targets for attacks. Large parts of the province are beyond government control, 
including Spera, Musa Khel, Sabari, Bak and Terezai. Despite this, in the perception of many tribal leaders, the fact that the government did not formulate a clear policy towards the tribes, is now coming back to haunt both the tribes and the government in the form of a virulent and powerful insurgency.

A significant window of opportunity, between 2002 and -- depending on the specific region -- 2009, is all but shut. Today, tribal communities are facing immense pressure from a number of sources, and their stance is often about what is most practical and will ensure their survival and safety.

“We cannot wear our turbans freely, or grow our beards too long, otherwise this makes the international military suspicious that we are working with al Qaeda. If we cut our beards short, we are accused of being puppets of the government, or spies".

In practice, this often leaves tribal elders with little room to manoeuvre and forces them to deal with different sides.

“For my own survival, I had to deal with the insurgents. I don't support them but I have to talk to them."

Many are simply unable to do anything to prevent their infiltration into their areas, or for pragmatic reasons have a member of the tribe or family working within an insurgent network. In areas where tribes feel the government is unable to protect them, they might strike a deal with insurgents in order to stay alive - this approach has become far more widespread in recent years and is more of a survival technique rather than ideological support. Thus, while the insurgency has gained ground in Khost and almost all tribes have segments within the insurgency, large parts of the population do not support the insurgency directly.

In areas where the government is unable to protect them, tribes will often now make deals in order to stay alive. ${ }^{17}$ As stated above, deals are struck a lot and are not necessarily a reflection of ideological support, but rather one of pragmatism. Elders from Khost mentioned that in a single family, one might be working for the government and one with the insurgency - and this for practical reasons of survival.

Other deals might be struck for economic motives. In Gurbuz district, which borders Pakistan, there are three border crossings, one official and two unofficial. Of the unofficial crossings, the ANSF have reportedly struck a deal with smugglers and insurgents and no taxes or customs 
officers levy taxes. The strength and the efficiency of the insurgency is therefore very much affected by how tribes and local government structures respond to them.

The insurgents clearly rely on a strategy of intimidation of tribal leaders as well but resentment has also mounted against ISAF. By and large the international military are deeply unpopular, with most respondents stating night raids and other military operations as fuelling local support for the Taliban (a term often used to talk about insurgent networks, even though they may not specifically be Taliban per se).

“The prominent tribal leaders now remain quiet because of the Taliban. If they show any support for the government, they would be killed, but no one wants to support the government anyway. Arrests and general harassment by the government and the IM forces have created a lot of resentment. The Taliban are now the most influential people in our area. "

At the same time, some elders acknowledge that if the international military leaves, problems would not simply disappear. Militants would still maintain pressure on tribal leaders and challenge their authority.

\section{Conclusion}

This brief has argued that as a result of decades of war and migration, as well as an increase in insurgent havens and regrouping facilities just across a porous border, the power within tribes has been weakened and shifted to religious leaders, and within those to the more radical ones, as well as to factional commanders who have seized power by force.

Secondly, the government's lack of a serious tribal engagement strategy when it had the chance between 2002 and 2009, has only served to marginalise otherwise supportive, pro-government tribal elements. As a result, the insurgency has garnered more strength. The resulting insurgency/counterinsurgency played out in people's homes and villages is putting tribal leaders under tremendous pressure. How important or realistic is a tribal engagement policy now? What can still be expected of tribal leadership, after all, when much of what has been said points to the fact that tribes have been weakened by the increasing influence of militant religious actors and the current insurgency/counterinsurgency dynamic?

A starting point is that the government would likely benefit by engaging with 
tribal leaders where the security situation is better and there are few kinetic activities, such as Tani, Gurbuz and Zazi Maidan. In other districts, the pace of engagement will have to be slower and a military or political settlement of the current conflict may have to be found first.

Nonetheless, the government should communicate their intentions and policies to all, sending a message to tribal leaders in more unstable districts that they will be engaged with in order to avoid the perception that only those from formers leftist strongholds, who generally had better connections to the government in the past, are benefitting from a tribal engagement policy. Greater care must be taken to ensure that there is a perception of equality of tribal representation in official positions. Resentment against other, more 'favoured' tribes (particularly the Tani), was cited several times as a cause for frustration and inter-tribal hostility.

Government officials at the district level have on occasion identified working with the tribal system as a critical means to ensuring security. It is important that the government at the central level recognizes that a constructive role for both local tribal and religious leadership is needed, and communicates this recognition with tribal communities.

The government can enhance the role played by tribal elders in their communities in specific areas:

- Resolution of resource-based conflicts;

- Access to and release of prisoners arrested by the GoA or IMF;

- Reintegration and reconciliation

In practical terms, this means having regular and genuine liaisons between community leaders and the government.

\section{Recommendations}

To the GoA and International Community:

- The Afghan Border Police (ANBP) must be strengthened and their numbers increased along this porous frontier zone. Historically, tribes have also played an invaluable role in securing the Afghan frontier, and it is important that they also be engaged in guarding border areas. Crossborder insurgent movement is a significant problem and a principle cause of heightened insecurity; insurgent networks also manipulate cross-border trade, which are engendering resource- conflicts as a result. Border crossings in 
Gurbuz, Zazi Maidan, Terezai, Tani and Spera must be secured.

- Reconnect the provincial capital with the districts. For example, the Zazi tribe in the north of Khost is almost completely cut off from the provincial centre as the road connecting the district to the centre passes through Bak and Sabari, two of the most insecure districts in the province and indeed wider region. Similarly, the Mangal districts to the West also suffer from this sense of isolation to the bustling provincial centre, exacerbating their economic situation and inability to do business; insurgents have taken advantage of this fact.

- High-level unresolved land conflicts must become priority issues for both provincial and district-level government. The possibilities for insurgents and criminals to exploit such conflicts among tribes must be mitigated through cooperation between traditional and modern conflict resolution mechanisms where possible. For example, the conflict between Kuchi and settled populations in Terezai continues to be a serious cause of insecurity in the area. Both the formal and informal justice systems have been eroded by decades of conflict, and although the informal justice system remains dominant it is also vulnerable to corruption. Thus state-backing of the informal justice system through a framework that complements both roles without undermining the integrity of the other.

- Stabilization initiatives at the district level should not only be centred around the district centre involving the administration, but should develop community participation initiatives. This is particularly important in more insecure districts, where typically government presence is limited solely to the district centres.

To the GoA:

- Avenues must be explored whereby district-level neutral and independent commissions are set up to deal exclusively with issues of restorative justice, and should be led by trusted and respected elders. This will go some way to addressing past wrongs within communities, as well as potentially providing an avenue to address wider issues of reintegrating local 
insurgents back into communities. Such a system should receive adequate backing from the government.

- Khost's youth should be supported and programmes implemented to provide an outlet for the city's student population - programmes on the importance of freedom of thought and action, sporting activities, activities designed to bring together and enable healthy discussions. This would ideally include the participation of teaching staff.

- Civil Society Organisations should be supported by both the government and potentially donors. Tribal shuras, for example, could be provided with forums and means to meet and discuss issues of importance - and should be able to liaise more easily with the provincial government.

- The influence of cross border insurgent networks and the problems of weak governance and tribal unity in Khost have spread to neighbouring provinces of Paktia as well. Furthermore, the fate of Loya Paktia, including Paktia, Khost and Paktika, in terms of security is interlinked due to overlapping tribal links and routes. A regional as well as provincial and district level approach is needed to address both cross border sanctuaries and the problems of the region.

\section{Endnotes}

1 See also TLO policy brief 1, December 2009, Tribal jurisdiction and agreements.

2 Sébastien Trives in Politique Etrangere -- Afghanistan: Tackling the Insurgency, the Case of the Southeast (2006)

3 This status as an economic hub could be further enhanced by the recently signed Afghanistan-Pakistan Transit Trade Agreement (APTTA), on October $28^{\text {th }} 2010$, facilitating trade across Afghanistan's border with Pakistan.

4 Supporting Thomas Ruttig's argument of the "void in the centre". See Thomas Ruttig (2006) Islamists, Leftists - and a Void in the Center. Afghanistan's Political Parties and where they come from (1902-2006). Konrad Adenauer Stiftung.

5 Source: UNAMA Southeast Region

6 Political parties active in Khost are: Republican Party (Sanjar), National Solidarity Party of Afghan Youth (Jamil Karzai), Afghan Millat (Ahadi), Mahaz-e Milli (Gailani), Nijat Milli Islami (Mojadidi), Afghanistan National Party (Qanooni), Solh-e Ghurzang (led by recently elected parliamentary member and former presidential candidate, Shahnawaz Tani), Da Afghan Wolas Mili Yowali Islami Tahrik (led by Maulawi Sayedullah).

7 The leftists are more active in Khost than elsewhere in Loya Paktia because it was their past stronghold.

8 'Kuchi' is not a tribal denomination, rather it is a term that is generally used to describe the nomadic pastoralists of Afghanistan. In fact it is a term that may cause confusion, since it refers to both a lifestyle (migratory), a production mode (livestock dependent), and a cultural identity. Three categories can be differentiated: 1.migratory, livestock dependent; 2. recently settled, formerly migratory, livestock dependent; 3. settled people, who still hold on to the cultural identity and refer to themselves as Kuchi. (F.de Weijer: "Towards a Pastoralist Support Strategy", USAID / RAMP Oct.2005). In Khost, there are believed to be approximately 210,00 Kuchis (about 32,000 families). The largest concentration of Kuchi in Khost are in Matun, Shamal, Lakan, Terezai, Bak, Yaqubi and Gurbuz districts. The largest tribal group of Kuchis in Khost province are the Ahmadzai (Ghilzai confederation of the Pashtuns), the second largest are the Niazi tribe. Both belong to the Ghilzai confederation of the Pashtuns. This stands in contrast to the majority of settled tribal groups in Khost belonging to the Kiryani tribe (another confederation). Hence the tensions between Kuchis and settled tribes are due to tribal differences and lifestyle 
(sedentary vs. migratory) (Information taken from the Tribal Liaison Office Kuchi workshop proposal, October 2008).

${ }^{9}$ Source: NSP

${ }^{10}$ Sébastien Trives in Politique Etrangere -- Afghanistan: Tackling the Insurgency, the Case of the Southeast (2006)

11 Who reigned between 1919 and 1929, and whose reforms and policies were seen as too modern and western. These prompted a number of protests in the more rural and conservative tribe-dominated areas.

12 Most Southeastern Pashtun tribes are distinct from their Southern and Eastern brethren. Except for the Ahmadzai, the Kharoti and the Suleimankhel who are Ghilzai, they belong to neither of the two most famous Pashtun tribal "confederations", the Durrani and the Ghilzai. The non-Ghilzai tribes of the Southeast live mainly in mountain valleys. The limited space for settlement means that they are relatively small and closely knit. Their traditional tribal institutions - the tribal leaders (the khan), the tribal intermediaries with the government (the malik), the tribes' egalitarian (but maleonly) decision-making body, the jirga, and their enforcement organ, the volunteer-based arbakai (plural: arbaki) - are significantly stronger than those of the lowland tribes. However, even among the Southeastern Pashtuns, these institutions have been partly weakened and superseded by powerful newcomers during almost 40 years of violence, coup d'etats, civil war, occupation and resistance: mainly by former mujahedin commanders. Loya Paktia's Insurgency: The Haqqani Network as an Autonomous Entity, Thomas Ruttig in Decoding the new Taliban (Giustozzi, 2009).

${ }^{13}$ Ibid.

${ }^{14}$ According to UN analysts in Kabul, the insurgency in Loya Paktia consists of 'several distinct groups' with 'numerous fault-lines' amongst each other (among them what they call the 'Haqqani tribal organisation or HTO') while other UN officials in the South-Eastern region call Jalaluddin and his son Serajuddin Haqqani 'Taleban commanders'. Loya Paktia's Insurgency: The Haqqani Network as an Autonomous Entity, Thomas Ruttig in Decoding the new Taliban (Giustozzi, 2009).

15 reportedly over the issue of chromite smuggling as both men benefitted greatly from this trade in Khost province.

16 Discussed in greater detail in TLO's Policy Brief on Reconciliation and Reintegration in the Southeast (September 2010).

17 Though this was also done in the 1980s with the Parchami government. 